\title{
OBSERVATIONS ON THE EUCALYPTS OF NEW SOUTH WALES.
}

PART V.

By Henry Deane, M.A., F.L.S., and J. H. Maiden, F.L.S. (Plates xxxvii.-xlii.)

E. Macarthuri, sp.nov.-The Camden Woolly-butt.

(Plate xxxviii.)

The history of this interesting species is as follows:- Sir William Macarthur collected its timber for the Paris Exhibition of 1855 , it bearing the number 142 of the indigenous woods of the southern district he was commissioned to procure for this Exhibition. Under the name of "Wooly Gum of Argyle," he described it as follows: "A species of picturesque growth, confined to a limited extent of country; wood not esteemed, reputed to possess little comparative strength or durability. Height, 40-80 feet; diameter, 36-48 inches."

The identical specimen was sent by Sir William to the London Exhibition of 1862, this time under the name of "Woolly Gum of Berrima," and it was described as "a tree of beautiful form, but the timber weak and worthless."

In the year 1864 Miss Atkinson (afterward Mrs. Calvert) collected it, and following is a copy of her label :- "Bark fibrous, Woolly Gum, Berrima. Large round tree, very hard wood, but not used, as it does not split well."

Her original specimens are in the National Herbarium of Victoria, and were seen by Bentham, who referred them to $E$. viminalis. See also B.Fl. iii. 240, where this species is referred to as "Camden Woolly Butt, Woolls."

Probably both Miss Atkinson and Dr. Woolls collected specimens, and the following passage was written soon after the 
arrival of the 3rd volume of the Flora Australiensis in the Colony :-

" $E$. diversifolia.-I have ventured to separate the "Camden Woolly-butt' from the 'Manna Gum' (E. viminalis), with which it has been associated, because the trees differ so much from each other in bark, habit, \&c. The Camden Woolly-butt resembles in some respects the Woolly-butt of other districts, having the lower part of the tree covered with fibrous bark and the upper branches smooth. The inflorescence, however, and the leaves are very different, being sometimes narrow-lanceolate and alternate, and sometimes cordate or ovate-acuminate, sessile and opposite. The buds and seed-vessels are small, generally eight in each axillary or lateral umbel. This species is common in the neighbourhood of Berrima, and attains the height of 80 feet, but beautiful as the form of the tree is, the wood is said to be indifferent." Woolls' Contribution to the Flora of Austratia, p. 235 (1867).

And again :- "E. diversifolia, which, in the Flora, is regarded as one of the forms of E. viminalis, is certainly a distinct species, and called 'Camden Woolly Butt.' The lower part of the tree is fibrous, and the leaves differ from narrow lanceolate and alternate to cordate, sessile and opposite."-Woolls' Lectures on the Vegetable Kingdom, p. 120 (1879).

It will thus be seen that Woolls did not agree with Bentham in placing the "Camden Woolly-butt" under E. viminalis, and he himself placed it under E. diversifolia. Woolls did this probably because he thought that the reference in B.Fl. iii. 240 to $E$. diversifolia was intended for the "Camden Woolly-butt," but it is not Bonpland's species, Mueller (Eucalyptographia, under $E$. viminalis), having shown that the plate in Pl. de Malmaison, 35 , t. 13 , represents a young state of $E$. santalifolia.

In 1885 Dr. Woolls (Plants of New South Wales, p. 55), departed from the opinion he had so long held as to the claim of the "Camden Woolly-butt" to be a distinct species, and looked upon it as a form of E. Stuartiana, a statement which could only have been made without due consideration. 
"E. Stuartiana has a wide range in New South Wales, being found on the Mittagong Range, the hills near Mudgee, and parts of New England. The bark is fibrous and persistent, and it is known by the popular names "Camden Woolly-butt," "Peppermint," or "Stringybark." On young trees the leaves are frequently opposite. It occurs on the Mittagong Range in company with $E$. amygdalina, and rises to the height of 100 feet." - $O p$. cit.)

A specimen of "Mudgee Peppermint," so labelled by Dr. Woolls, is E. Siuartiana, and is not identical with "Camden Woolly-butt" as surmised by him on the label. This confusion of the two trees probably arose from the mixing of herbarium specimens. Peppermint is a bad name to apply to this tree, and doubtless arose simply from contemplation of its fibrous bark, which somewhat resembles that of some species known as "Peppermint." The leaves of the "Camden Woolly-butt" emit no odour of peppermint.

We name this species in honour of the late Sir William Macarthur, of Camden Park, who appears to have been the first to recognise this particular Woolly-butt as a distinct tree, while he was certainly one of the pioneers in the difficult task of diffusing accurate information in regard to the Eucalypts of New South Wales.

Vernacular name._- Camden Woolly-butt," after the county of Camden, New South Wales; it has, however, been found in the county of Argyle also; in fact it was originally called "Woolly Gum of Argyle." The name "Woolly-butt" or "Woolly Gum " is in reference to the texture of the bark and sap wood. It is not to be confused with the common Woolly-butt of the Sydney district (E. longifolia), the Woolly-butt of the South Coast ( $E$. saligna), or that of the North Coast (Tristania conferta).

Bark.-Rough, somewhat box-like, but very woolly. The sapwood also of a woolly texture.

Timber.-Pale coloured, nearly white. Not a favourite locally as it does not split well and is not durable. Additional notes on the reputed value of this timber have already been given. 
Seedling leaves.-Linear-lanceolate, slightly cordate, barely stemclasping, strictly opposite.

Sucker leaves.-Cordate or ovate-acuminate, stem-clasping, sessile and opposite. Bright green in colour; of similar tint on both sides.

Mature leaves.-Alternate, narrow, lanceolate, often falcate, thickish, of equal colour on both sides. Venation not prominent; intra-marginal vein at some distance from edge; veins not springing from the base, pinnate.

Buds.-Small, the operculum and calyx of approximately equal size, the former but very slightly conical; shining; up to eight in the head but perhaps five on the average. Umbels axillary, with short scarcely flattened stalks, and stalklets absent or nearly so.

Anthers. - Small, ovoid in shape, opening in longitudinal slits; inflexed in bud; apparently all fertile. Stigma slightly dilated, having the appearance of being flattened on top.

Fruits.-Very small, much smaller than that of E. Stuartiana. Nearly hemispherieal, slightly dilated at the rim, which is well defined; valves usually three but rarely four, scarcely exserted. Seeds small, without any appendage.

Range.-Confined to the counties of Camden and Argyle, N.S.W., as far as known at present.

Prefers swampy or low-lying land, or to follow the course of a stream.

Affinities.-Bentham indicates its affinity to E. viminalis, but except in the suckers and mature leaves the affinity does not appear to be marked. Its narrow sucker leaves and small fruits should prevent its confusion with E. Stuartiana. The sucker leaves sharply separate it from $k$ : acaciceformis.

E. quadrangulata, sp.nov.

(Plate xxxix.)

A tree of 80-100 feet and diameter of 2.4 feet.

Bark.-Very much resembles that of ordinary Box (E. hemiphloia) in general appearance, but bark more fuzzy and less soft 
than the latter; the timber also lighter in colour. The branches have smooth tips.

Timber.-Pale, not brown when fresh like E. hemiphloia, inlocked, very tough, evidently an excellent timber. The rougher bark falls off in patches, leaving box-like but less rough patches underneath. Again, these less-rough patches become darker and more rough, and this process is repeated ad infinitum.

Kino.-On a tree being cut into a pocket of kino of a treacly consistency and colour exuded, which in a few hours dried into a hard, dark brown mass, which broke with a bright fracture. It is all but insoluble in alcohol and soluble in water, forming a rich tawny solution with deposition of gum on addition of alcohol, and thus belongs to Maiden's gummy group of kinos.

Sucker leaves. - Narrow-lanceolate, cordate and clasping at the base, strictly opposite, markedly paler on the under surface.

The sucker foliage of $E$. goriocalyx presents considerable similarity to that of E. quadrangulata, differing chiefly in the greater breadth and shorter length of the former.

The sucker stems are brown (commonly chocolate-brown) and usually square in section. Not only is the young stem quadrangulate, but it is even winged, and this is so marked a character that the name alata would probably have been chosen had this name not been preoccupied.

Other instances of quadrangular stems in Eucalyptus are :-

$E$. tereticornis (apparently not common), E. globulus, and $E$. Maideni.

The E. elata of Dehnhardt has also quadrangular stems. It has been placed under $E$. viminalis by Bentham, but that is an obvious error, and its position must remain in doubt until adequate material be available. Mueller (Eucalyptographia) suggests $E$. amygdalina, with which we also cannot concur.

Mature leaves.-Branchlets angular, lanceolate or narrowlanceolate, slightly falcate, usually 4 to 6 inches long, scarcely paler on the under surface.

The margin usually sinuate, jagged or remotely denticulate. Venation conspicuous on both sides, the intra-marginal vein con- 
spicuously removed from the edge, the lateral veins spreading. The texture of leaf thickish, hence the oil-dots, which are fairly numerous, are not prominent.

Buds.-Umbels axillary, consisting usually of 4 to 8 in the head, not dull; sessile, the common stalk being broadish and strongly compressed. The calyces sub-conical and exceeding the operculum, which is conoid, the calyces sometimes angular.

Stamens all fertile, inflexed in bud, opening with longitudinal, almost parallel slits.

Fruits.-Small, shining, bell-shaped, rim medium, the valves slightly exserted, and usually three in number. The seeds small, without membranous expansion.

F. quadrangulata presents points of similarity to E. saligna, E. goniocalyx, and E. Macarthuri.

It shows affinity to $E$. saligna in its kino (it is a member of Maiden's Gummy group). In the occasional angularity of its buds and in the general shape of the fruits, there is some approach to $E$. saligna, but the buds of the latter are more pointed, the fruits more cylindrical and the rim more sunk, while the venation of the leaves and the texture of the bark show that the species are very different.

We have already alluded to the similarity of E. quadrangulata and E. goniocalyx as regards sucker-foliage. The similarity of the mature foliage of the two species is unmistakable and extends even to the margins; very large leaves have not, however, yet been found in E. quadrangulata. The shape of the fruits is, however, quite different, while E. quadrangulata is a Box and $E$. goniocalyx a Ribbony Gum.

E. quadrangulata possesses no close affinity to the common Box (E. hemiphloix).

The sucker foliage of E. Macarthuri is sufficiently distinct from that of E. quadrangulata, nor are the stems of the former angular. The mature foliage of the two species is not dissimilar. The fruits of E. Macarthuri are rather smaller and the valves less exserted. Both species have fibrous barks, but one belongs to 
what is known as the Box group of barks, and the other to the Woolly-butt group; the timbers also are very different.

Range.-This species has a very limited range, so far as is known at present, having been found only in the neighbourhood of Hill Top, about 70 miles south of Sydney.

E. ACACIEFORMIS, sp.nov.

(Plate xxxvii.)

A large, rather umbrageous tree, attaining several feet in trunk diameter (Mr. A. R. Crawford says " over 6 feet").

Vernacular names. - This is recognised as a "Peppermint" in New England, and sometimes, by way of distinction, "Black," or "Narrow-leaved Peppermint." The term "black" is in allusion to the dark colour of the bark as compared with that of $E$. Stuartiana.

It is the Eucalypt No. 3 of p. 542, Vol. vii , Proc. Aust. Assoc. Adv. Science ("Some Eucalypts of the New England Table-land," by J. H. Maiden).

Bark.-Sub-fibrous, resembling that of E. piperita a good deal.

"Sometimes very rough and furrowed, almost like an Ironbark."-(A. R. Crawford, in litt.)

Timber.-Pale reddish.

Seedling leaves.-Narrower than the suckers, but otherwise very similar. They are strictly opposite.

Sucker leaves.-Pale coloured, lanceolate, symmetrical, always blunt at the apex which is somewhat rounded. The margin is crenulate, a very unusual circumstance in a Eucalypt; and the leaves are alternate, and not opposite as is the case of normal Stuartiana. The average size of the young leaves is $1 \frac{3}{4} \times \frac{5}{8}$ in.

Mature leaves.-Lanceolate, the average size of the leaves being: $2 \frac{3}{4} \times \frac{1}{2}$ in. The foliage is not glaucous in any part, not even the sucker foliage. Margins often crenulate. Equally green on both sides. The intra-marginal vein distinctly removed from the edge; the transverse veins fine, nearly parallel, and at about an angle of $45^{\circ}$ with the midrib. 
Buds. - Commonly up to 6 or 7 in the head; stalklets short and angular; stalks usually 4 or 5 lines long, very angular or flattened. Operculum a little pointed; about equal in size to the calyx; style short and the stigma dilated somewhat. The anthers opening in parallel slits.

Fruit.-Small, with short stalklets; the stalks of about twice the length, roundish, being only slightly compressed. The valves scarcely exserted, and usually only three. Shape of fruit rather more cylindrical than hemispherical, $\frac{3}{16}$ broad $\times \frac{7}{32}$ inch long. Rim of medium width and nearly horizontal.

Range-Confined to New England as far as observed at present. Common between Yarrowitch and Walcha; also near Moona Plains. Occurs also near Glen Innes and (sparingly so far as observed) in the Tenterfield district, e.g., near Mount Spiraby, east of Bolivia.

\section{Eucalyptus aCacieformis, var. Linearis, var.nov.}

The Eucalypt referred to as No. 4 at p. 542, Vol. vii., Proc. Aust. Assoc. Adv. Science.

A singularly graceful tree, reminding one of a Weeping Willow. Height about 50 feet and trunk diameter 2 feet, as far as seen.

The twigs are slender, a characteristic of the tree being the smallness and the grace of its parts.

Vernacular names.-A "Peppermint" or "Narrow-leaved Peppermint." "Grey Peppermint" (H.D.).

Bark and timber similar to preceding

Sucker foliage.-Has crenulated margins like the preceding, but longer, narrower, and more pointed leaves. Some of the very young foliage is linear-lanceolate and even linear.

A good deal of the young foliage reminds one superficially of that of the Wilga (Geijera parviflora).

Alternate, not opposite like E. Stuartiana.

Mature foliage.-Linear-lanceolate or lanceolate, the average dimensions being, say, $5 \times \frac{3}{8}$ in. 
Fruits.-Smaller than the preceding, reminding one of those of $E$. microtheca, but the calyx less hemispherical. Valves well exserted. Pedicels on the average as long as the fruits; the common peduncle also much longer than that of either of the preceding forms.

Range.-New England (Walcha and Glen Innes districts).

\section{E. RUBIDA, sp.nov._-“Candle-bark."}

(Plate xl.)

Vernacular names.-Known as "Flooded Gum" at Queanbeyan, Michelago, Cooma; sometimes known as "Bastard White Gum," "Ribbony Gum," and "Drooping Gum." The name "Candle-bark" in use in the Queanbeyan district is in reference to its smooth and glaucous trunk; it is very descriptive of the tree as seen in much of its range and might be adopted for the vernacular, as the others are already appropriated. It has usually reddish or plum-coloured patches on the bark, hence the occasional name of "Spotted Gum." Sometimes the bark is, however, of a yellowish cast (the tips of the twigs being also yellowish) and hence, between Goulburn and Moss Vale, it is one of the trees known in the district as "Yellow Gum." We have also noticed the species to have a yellowish bark between Delegate and Bombala, while a label in the National Herbarium, Melbourne, shows that the species at St. Vincent's Gulf, S.A., is also known as "Yellow Gum."

Bark.-Perfectly smooth for the most part, the outer layer of bark falling off in ribbons. The "bole and limbs very white, as if whitewashed" (A. W. Howitt, referring to Gippsland trees). The name "Candle-bark" is also excellently descriptive of the appearance of the bark in the most southern parts of this Colony and in north-eastern Victoria.

It frequently exhibits reddish or plum-coloured patches (hence the specific name); this is a colour rarely, if ever, seen in $E$. viminalis. Sometimes (e.g., Adaminaby to Cooma) the colour of the bark, especially of the branches, may be described as pale 
pink. We have already referred to the yellowish cast of the bark in widely different localities.

In the case of a species having such an extended range, it is not surprising that the bark shows some variation. For example, the trees about Sunny Corner show perhaps a rougher (more flaky) bark at the butt than is usual in many other localities, but neither here nor anywhere else is such rough bark ever of a fibrous character.

Under E. Stuartiana, in the Eucalyptographia, the following remarks occur:- "It is possible that in this species a smoothbarked variety occurs, as would appear exceptionally to be the case, according to the notes of several collectors." We do not doubt that E. rubida is here referred to, and the reasonableness of the confusion with E. Stuartiana is referred to below.

Timber.-Red worthless timber; dries paler.

Sucker leaves.-From nearly orbicular to nearly oblong, often emarginate or retuse, eventually taking on a lanceolate shape. The midrib usually terminating in a short and fine point. Strictly opposite; sometimes stem-clasping and even more or less connate. Very glaucous as a general rule.

Mature leaves._Dull green; of similar tint on both sides; narrow lanceolate, of thickish texture and hence largely concealing the oil-dots, the intramarginal vein scarcely removed from the edge, the primary veins roughly transverse. Often glaucous, sometimes very much so. Spherical brachyscelid galls are sometimes found on the leaves.

Buds.--Ovoid, axillary; in threes and cruciform; sessile or with very short stalklets; the stalks commonly under $\frac{1}{4}$ inch long, round, rarely flattened, and then only towards the insertion of the buds.

Operculum.-Nearly hemispherical when ripe, hardly pointed; rather shorter than the calyx; conoid when less ripe.

Stamens all fertile and inflected in the bud, anthers ovateoblong, with parallel distinct cells.

Fruit.-Top-shaped; spreading at the orifice. Usually about 3 lines in diameter. Sometimes nearly hemispherical. Shiny or 30 
glaucous. The rim broadish and convex. Valves three or four and exserted.

Affinities. - It has been variously looked upon as a broadsuckered form of E. viminalis, or a smooth-barked form of $E$. Stuartiana, while its affinity to E. Gunnii though less strong is still obvious. We will give a few notes in regard to these three species.

It resembles $E$. viminalis in its drooping foliage, flowers in threes, and smooth bark. It is Howitt's viminalis $(b)$. See "Eucalypts of Gippsland," p. 97, to which excellent account of the tree the student should turn, its affinities to E. viminalis and $E$. Stuartiana being there clearly indicated. It sharply differs from $E$. viminalis in its broad glaucous suckers.

It shows obvious affinity to E. Stuartiana in its broad suckers; its most obvious differences lie in its smooth bark and thinner leaves.

Its most obvious similarity to $E$. Gunnii lies in the fact that it is a smooth-barked Gum with broadish sucker leaves; it may at once be distinguished from that species by the flowers in threes (a constant character of E. rubida as far as known), less ovate sucker leaves and uniformly narrower mature foliage.

"E. Gunnii, Miq., in Ned. Kruidk. Arch. iv. 126 (not of Hook. f.) from Streleczky Range, Victoria, appears to be $E$. viminalis" (B.Fl. iii. 240) is probably E. rubida.

Range.-The mountain ranges in the south and south-eastern portions of the Colony. Occurs on the lower slopes of the Mt. Kosciusko ranges up to about 5000 feet. Common about Jindabyne, Adaminaby, Delegate to Bombala and Cooma, Michelago, Queanbeyan; northerly nearly as far as Moss Vale; westerly as far as Sunny Corner and the tributaries of the Turon. Extends also to Victoria and South Australia (St. Vincent's Gulf).

Its name of "Flooded Gum" of course indicates the low-lying localities in which it is found, but it is by no means restricted to such situations, occurring in well drained, hilly situations in the southern and western mountain ranges. 
Miscellaneous Notes (including descriptions of new varieties).

\section{i. RENANTHERE.}

E. regnans, F.v.M., and E. Fastigata, D. \& M.

The giant tree of Victoria was not formally described in the first instance. Under $E$. amygdalina, Baron von Mueller first refers to a tree which attains a height of over 400 feet, with "a smooth stem and broad leaves." . . . " this species or variety which might be called Eucalyptus regnans. . . . ." (Rep. Acclim. Soc. Vict. 1870, p. 48).

The statement as to "smooth stem and broad leaves" is repeated at p. 114 of his Select Extra-tropical Plants, N.S.W. Edition (1881), it being contrasted with $E$. amygdalina, "which has small narrow leaves and a rough brownish bark."

At p. 236 of the Key to the System of Victorian Plants, Mueller first botanically defines $E$. regnans. He says: "bark outside whitish and smooth, except at the stem-base," and calls it "Giant Gum tree" and "Spurious Blackbutt."

Our E. fastigata (Proc. Linn. Soc. 1896, p. 809) is a tree with a fibrous bark, not to be distinguished, in this respect, from $E$. obliqua except in the smooth branchlets of the former. Mueller described his regnans as a smooth-barked tree; the fruit of our fastigata (from Mt. Tantawanglo) is smaller than that of $E$. regnans, and there are other differences, of more or less value, which caused us to look upon our tree as new to science.

We have since studied the distribution of E. fastigata and find that it is very widely diffused in New South Wales. Following are some localities :-

Northern District. - New England.

Southern District.-Most mountain ranges, extending at least as far north as near Moss Vale.

Western District.-Jenolan Caves, Mt. Tomah (where it is a giant tree), Tarana ("Messmate"), Burraga ("Blackbutt"), Cowra ("Red Blackbutt"). Hence it occurs in most of the high mountainous districts of the Colony. 
Contemplation of these specimens (for the most part collected by ourselves) and inspection of $E$. regnans as it grows in Victoria incline us to the opinion that our E. fastigata may not be specifically different from E. regnans. Mueller's description of his species would require to be modified in the specially important matter (in the case of a Eucalypt) of the bark, while the size of the fruit and other minor matters in which the published descriptions of E. regnans and E. fastigata do not agree, may not present insuperable obstacles to the fusion of the two species.

An excellent account of $E$. regnans is given by Howitt in his Eucalypts of Gippsland (Trans. Roy. Soc. Vic. ii. 87), and he observes that it goes under the name of "Blackbutt" in Victoria.

E. amygdalina, Labill., var. nitida, Benth. (B.Fl. iii. 203).

We have specimens from Jenolan Caves, N.S.W., which closely resemble Hooker's E. nitida as figured in Fl. Tas., and may be arranged under Bentham's variety.

E. Dives, Schauer.

(Syn. E. amygdalina, Labill., var. latifolia, Deane \& Maiden, Proc. Linn. Soc., (2) x. 609, with figure.)

See also Woolls' Flora of Australia, p. 241, except as regards height of this species, which, while it flowers as a shrub, attains the size of a medium-sized tree.

Common on the southern and western spurs of the Great Dividing Range.

E. Muelleriana, Howitt.

Trans. Roy. Soc. Vict. Vol. ii. 89 (with figs. 11 and 12), is, in our opinion, identical with E. dextropinea, R. T. Baker, Proc. Linn. Soc. N.S.W. 1898, 417.

In the Goulburn district it is known as "White Mahogany," but it is not to be confused with E. acmenoides. Its branches are rough to the top, affording a ready distinction between it and $E$. pilularis. The bark is very yellow when freshly cut, also the 
timber, hence its Gippsland name of "Yellow Stringybark." The timber is valued for building purposes, being used for flooring, and weatherboards, dc. It occurs in many places in the coast mountain ranges, both north and south.

E. siderophloia, Benth., var., glauca var.nov.

This is the glaucous interior form of the species, which goes under the names of "Blue-leaf Ironbark" (in allusion to its glaucous foliage) and "Broad-leaf Ironbark," in allusion to its broad sucker-leaves. Its operculum is shorter than that of the normal species, but the fruit of var. glauca and of the type are precisely similar except as regards glaucousness.

Dubbo district (H. Deane, Nov., 1892 ; J. V. de Coque and J. L. Boorman, Nov., 1897). This form (from fragments in our possession) will probably be found to have extended range easterly, and more particulary northerly of the Dubbo district.

"Broad-leaf Ironbark." Mr. J. V. de Coque recently drew attention to this tree, and pointed out that its timber is inferior to that of the other Ironbarks of the Dubbo district. Its timber is of an inferior quality, both as regards "ringing" and "splitting" (cracking), so much so that the timber-getters never cut it except for rails. Mr. Boorman points out that it grows on slightly elevated lands, and is confined to such situations only. When growing in the forest it can readily be noted by its glaucous appearance.

The "Blue-leaf Ironbark" is not really different from the preceding, although local people point out differences in breadth and glaucousness of leaves.

It bears a strong superficial resemblance to a specimen in the National Herbarium, Melbourne (in bud only), collected by Clarendon Stuart in "New England, 1,000-1,500 feet" (New England is never as low as this, so it must have been collected during an ascent). His label further states - "30-40 feet, bark very rugose and deeply furrowed, flowers light yellow, Mountain Ironbark, No. 128." It bears a label in Mueller's handwriting "E. leucoxylon," and is probably the var. pallens of Bentham 
(B.Fl. iii. 210). Ample botanical material is desirable of these aberrant forms; at the same time it is not suggested for a moment that there are not two glaucous species, the stamens and stigma of $E$. siderophloia and $E$. leucoxylon (sideroxylon) being very different.

\section{E. Goniocalyx, F.v.M.}

$$
\text { (Plate xli., figs. 1-3.) }
$$

In this colony this species is sometimes known as "Yellow Gum," owing to the yellowish cast of the foliage (especially when young), of the bark, and of the timber (particularly when fresh). There are several so-called "Yellow Gums" in New South Wales, but they must not be confused with the "Yellow Box" or "Yellow Jacket" (E. melliodora), sometimes called "Apple" at Orange, it being confused with E. Stuartiana. It is known as "Bundy" at Burraga and Rockley, according to Mr. R. H. Cambage.

It is usually found in gullies-bottoms or sides--and prefers good soil. It attains a diameter of 6 feet, and with 80 or 90 feet of barrel. Its timber has been passed both for Tallow Wood ( $E$. microcorys) and Box (E. hemphloia), but it more closely resembles the former. It is very hard when dry, and nails do not readily drive in it; hence it is not so well liked for building purposes as some softer but inferior timbers. It stands well in the ground. A correspondent informs us that he is again using some posts of this timber which have been in the ground for 30 years.

E. goniocalyx is found on the southern and western spurs of the Dividing Range. In a stunted form (as "Bundy") it occurs on hills as far west as Mudgee and Bathurst, but in the Blue Mountains and on the southern line north as far as Hill Top it is a magnificent tree.

In Woolls' "Contribution to the Flora of Australia," p. 230, he speaks of E. Stuartiana, var. longifolia, as the "Yellow Gum" of Wingecarribbee "and other parts of the interior" (sic). . . . "This gum bears some resemblance to the Grey Gum and Hickory of the County of Cumberland." The former was called by Sir William Macarthur "Yellow Gum of Berrima," and is E. gonio- 
calyx. The Grey Gum or Hickory is E. punctata, DC., as has already been pointed out by Mueller in the Eucalyptographia. It will be observed that both trees are placed by Bentham (B.Fl. iii. 244) under a variety longifolia of E. Stuartiana, which variety name should now be dropped.

E. Goniocalyx, F.v.M., var. Nitens, var.nov.

(Plate xli., fig. 4.)

With small, shiny fruits, up to seven in the head as seen, differing from the type both in the smallness of the fruits and in their shininess, those of the normal species being lustreless. The form formerly known as E. elceophora, F.v.M, is intermediate between var. nitens and the normal species.

"Silver Top Gum," Glenbog, Candelo (J. Duff); "Silver Top," Mountain Top, Nimitybelle; "Giant Gum," "Mountain Gum," Delegate River (W. Bäuerlen); Mt. Mueller, near Mt. Baw Baw, Victoria (Jas. Melvin), specimens received from Mr. J. G. Luehmann.

In this variety many of the leaves have the sinuous margins which appear to be characteristic of the species.

E. goniocalyx, F.v.M., var. Pallens, Benth. (B.Fl. iii. 230.)

"Rough-barked mountain apple," mountains on Snowy River (Mueller); Rob Roy, Queanbeyan (H.D.); Tumut (W. S. Campbell).

Has a box-like grey, persistent bark, like $E$. hemiphloia and $E$. Stuartiana. Is a stunted, twisted, crooked tree, not straight as $E$. goniocalyx usually is. Leaves often very long.

This is not to be confused with our E. Gunnii, var. glauca, the white dried herbarium specimens of which bear some resemblance to it; the latter is a smooth-barked tree.

This glaucous form bears resemblance to the glaucous form of $E$. goniocalyx, consisting of small, rather stunted trees on hills in the Bathurst and Mudgee districts. These resemble some South Australian specimens very closely, and are more glaucous than the normal species, though far less so than var. pallens. 
E. GunniI, Hook. f., var. Glauca, var.nov. (Plate xlii., figs. 5-7.)

This name we propose for the very glaucous form of this species (far more glaucous than the typical Tasmanian form), the whiteness of the fruits being especially marked. It is not uncommon in the Snowy Mountains of both this colony and Victoria (including summit of Mt. Baw Baw, Mueller), and we have it from as far north as Nimbo Station, head of the Queanbeyan River $(H$. Deane), where it is known as "Flooded Gum " and "Cabbage Gum."

E. Gunnii, Hook. f., includes, in our opinion, E. paludosa, R. T. Baker (Proc. Linn. Soc. N.S.W., 1898, p. 167).

We have specimens of typical $E$. Gunnii from Tasmania which tally with Hooker's description, and are accurately represented by his figure in Fl. Tas. We find on the same twig fruits of the shape depicted by Hooker, and of the conical form depicted by Mr. Baker as E. paludosa. We find such characters as the undulations of the leaf not constant; and having studied the species in the field for many years, and having examined a large series of specimens from Tasmania, Victoria, and also New South Wales, as far north as Hill Top, southern line, we fail to find a line of demarcation between them sufficient to constitute a second species. The variety name paludosa might perhaps, however, be retained to indicate the extreme conical fruited forms, but the tree is not absolutely restricted to marshy localities.

E. Saligna, Sm., var. Parviflora, var.nov.

$$
\text { (Plate xlii., figs. 1-4.) }
$$

This is a tree from northern New England (Bluff River near Tenterfield; also near Red Soil Creek, Mt. Spiraby, east of the Dividing Range) which bears the local name of "Silky Gum," owing to the sheen of its bark. It was also called by some people "White Gum" and "Blue Gum."

It is a very large tree, with smooth and sometimes almost glaucous bark, a little ribbony at the butt. Some of the trees resemble Blue or Flooded Gum (E. saligna) a good deal. In other 
cases it forms a gnarled tree up to 7 or 8 feet in diameter as seen, the scrambling branches in some cases actually touching the ground. Such trees remind one of Angophora lanceolata.

The gnarled trees have buttresses spreading over a large area of land, and have thin scaly or ribbony bark extending a good distance up the trunk; in others the roughish bark extends but a short distance.

The trunk and branches show patches of bluish, purplish or reddish. The twigs are often red, so are the young suckerstwigs, midribs and margins.

The tree is what bushmen recognise as a broad-leaved Gum in comparison with other species. The young foliage is especially broad, shining, particularly on the upper surface, and bears some superficial resemblance to pear-foliage.

Apparently rich in oil which has a peculiar and somewhat penetrating odour as tested by the crushed leaves.

The buds are clavate; the fruits are much smaller than those of the normal species; the valves are not exserted. The timber also appears to be different to that of the normal species.

The same tree occurs in the Blue Mountains (e.g., the Valley, Springwood, and also Jamieson Valley, Wentworth Falls (found in the latter place by W. Forsyth), and careful search will doubtless reveal its presence in localities between New England and the Blue Mountains.

E. pulverulenta, Sims.

We have observed a double operculum in this species at Marulan, N.S.W. E. cinerea, F.v.M., is Howitt's variety lanceolata of this species. Mueller desired to abandon E. cinerea, but Bentham (B.Fl. iii. 239) objected for reasons stated. We have an absolutely perfect series of specimens connecting $E$. pulverulenta and E. cinerea, and trust that the latter name may now be finally dropped.

\section{E. tereticornis, Sm.}

This is one of the most widely diffused Eucalypts in New South Wales. It presents a considerable amount of variation, and we offer notes on some of its varieties. 
E. tereticornis, Sm., var. dealbata, var.nov. (Syn. E. deaibata, A. Cunn., B.Fl. iii. 239).

\author{
(Plate xli., figs. 5-8.)
}

Bentham (loc. cit.) says that this may prove to be $E$. pallens, DC., in which case this must fall. Mueller was (at all events at one time) of opinion that $E$. dealbata, A. Cunn., was a form of E. viminalis, Labill., but having considered a very large number of specimens and having studied this form in the field for years and over a large area, we do not hesitate to place it under $E$. tereticornis.

Cunningham's specimens, as described in Walp. Rep. ii. 924, were obtained from the Wellington Valley; we have collected in this locality and have also examined authentic specimens in the National Herbarium at Melbourne.

If Western New South Wales specimens of E. tereticornis be examined, even from as far east as the Blue Mountains and Richmond, the fruits (as compared with the type form) will be found to be smaller, the rim flatter (more horizontal), the valves less exserted, the operculum shorter (it and the calyx being altogether smaller) and, particularly west of the Blue Mountains, the foliage and inflorescence become more glaucous. In other words, the transition between the normal tereticornis and A. Cunn.'s dealbata is absolute.

Following are some notes on and localities of actual specimens:

Adelong Crossing (W. Woolls), Tumut(Forest Ranger Mecham), Wagga Wagga (J.H.M.). One of the so-called White Gums from the neighbourhood of Bathurst and Mudgee (see further notes in Woolls' Flora of Australia, p. 228). Collected also by A. G. Hamilton. "Red Gum," "Cabbage Gum," Grenfell (Forest Ranger Postlethwaite). "This tree is called Cabbage Gum on account of its small size and crooked, stunted shape. It is most difficult to get a straight $l o g$, either from branch or trunk, of even $4 \mathrm{ft}$. in length. The bark is smooth and grey, similar to the Red Gum (E. rostrata) both on trunk and limbs . . the whole tree appears to be the Red Gum in miniature except that it does not grow straight. Sometimes used for fencing where no 
other timber can be obtained, such as on rocky hills, where it is generally found, and where carting other kinds is difficult." (Mr. Postlethwaite in litt.).

Cowra; Wellington (A. Cunn., W. Woolls, J.H.M.); Forbes; Mt. Tyriga, reputed centre of N.S.W., near Condobolin (H.D. \& J.H.M.). This is a tree which, if growing in the Sydney district, would, as regards its bark, be judged to be Grey Gum (E. punctata).

Eremeran, near Dandaloo, "Stunted Gum; grows on stony ridges; seems to be allied to Mallee" (Forest Ranger Kidston).

Dubbo, Peak Hill and Harvey Range (J.H.M.). A scaly, half-barked tree, but sometimes with bark as smooth as normal tereticornis. The amount of scaly bark varies a good deal. Tree strikingly like Mr. Postlethwaite's "Cabbage Gum." Buds markedly yellow.

Gundong or Quandong Creek, a tributary of the Bogan (Rev. G. A. C. Innes. See Woolls' Flora of Australia, p. 255).

Hills near Mudgee (Woolls); New England (C. Stuart).

Speaking generally, it is found in much of the western interior, southern, central and northern. It, however, is found east of the Dividing Range, e.g., we have specimens from the Hawkesbury district.

The buds and young shoots of E. tereticornis (e.g., from Williams River and Tenterfield) are sometimes glaucous; the trees do not otherwise answer to the description of var. dealbata.

E. tereticornis, Sm., var. brevifolia (B.Fl. iii. 242).

Through the kindness of Mr. J. G. Luehmann, we have received an authentic specimen of this variety. It is that form of E. tereticornis figured in the left of the plate of this species in Eucalyptographia. It is the "Orange Gum" or "Lemon Gum" of the Port Macquarie district, according to Mr. Forest Ranger Brown. The tree is abundant at Honeysuckle Flat, under 10 miles south of Port Macquarie (J.H.M.), but the leaves from that 
locality are as long as those of the normal species, those of Mr. Clarendon Stuart (on which the variety was founded) being simply abnormally small, having been collected from very exposed situations at some elevation above the sea. We have seen other specimens, also collected by Clarendon Stuart, which connect the above with those from the coast (Honeysuckle Flat).

The variety is, however, so interesting that the following notes in regard to it will be acceptable :-

On ironstone and serpentine soil at Honeysuckle Flat, 8 to 10 miles south of Port Macquarie.

There are a few hundred trees, attaining no great size, say, 18 inches to 2 feet diameter, 12 feet to first fork, and 30 feet high. The timber is very deep red, especially when freshly cut. When cut the tree spirted out sap abundantly, admixed with brown decayed matter. The sap is sourish and unpleasant to the taste.

The bark of the trunk is not to be distinguished from Forest Red Gum, except perhaps at the butt, in which it shows a tendency to form a thin scaly white outer bark of a box-like character.

Habit of the tree spreading and less drooping than ordinary Forest Red Gum (Eucalyptus tereticornis). The limbs are very brittle.

The rim of the calyx in this Gum is very marked. The operculum and calyx are full of oil-dots. The leaves are thinner than those of the normal species, while the veins are finer and less prominent; the intra-marginal vein is not so far distant. The peduncles are much broader and flatter than in the normal species; the pedicels likewise are broader and flatter. The operculum is subcylindrical, much longer than the calyx, but the calyx is larger and the operculum smaller than in the normal species. The operculum is narrower than the calyx, giving the appearance of "egg in egg-cup" or acorn and cup. This shape appears to be characteristic, and we offer it as a ready method of distinguishing this variety. The pedicels are flat and thick, running into the calyx without any very marked line of demarcation. The calyx 
therefore is subconical. The whole fruit is coarser in appearance than is that of the normal species.

The variety is a well marked one, although, as has been indicated, the name given by Bentham is unfortunate.

E. tereticornis, Sm., var. Latifolia, Benth. (B.Fl. iii. 242).

$$
\text { (Plate xli., fig. 9.) }
$$

"Leaves ovate to lanceolate. Flowers with a strong cimicine smell." The only locality in the Flora for this variety is Shoalwater Passage, Queensland (R. Brown), but the variety, or at all events one of its numerous links with the normal species, is tolerably abundant in the coast and coast mountain districts of the Colony, both north and south of Port Jackson.

"Flowers with a strong cimicine smell" appears to give the clue to the name "Stinking Gum" which in some parts of the Colony is given to E. tereticornis (see Agric. Gazette N.S.W. 1898, 593), though in the specimens collected in the Mount Seaview district the leaves were not specially broad. It is, however, not likely that bad odour is a character exclusirely possessed by the flowers of the variety.

These broad-leaved forms are usually (though not exclusively) found in swamps and flats, hence the local names "Swamp Gum," "Red Swamp Gum," and here we would point out that the habitat "Forest Red Gum" (E. tereticornis) as compared with "River Red Gum" (E. rostrata) is only generally and not absolutely true. This is an instance of the difficulty and even impossibility of giving entirely satisfactory vernacular names to many species of Eucalyptus.

We may point out that the timber of the broad-leaved forms is of very inferior quality (Mr. Forest Ranger Rudder, Agric. Gazette N.S.W. 1896, p. 15, says "nearly worthless"), and this enables us to understand the conflicting statements sometimes published in regard to E. tereticornis timber, which normally is one of the most valuable timbers we have. As a general rule it may be stated that Eucalyptus timbers grown in moist situations are deficient in durability and strength. 


\section{EXPLANATION OF PLATES.}

Plate xxxvii. - E. acaciaformis, sp.nov.

Fig. 1.-Twig with buds and flowers.

Fig. 2.-Twig (sucker) with crenulate marginal foliage.

Fig. 3.-Vertical section through bud.

Fig. 4.-Anther.

Fig. 5.-Fruits.

Plate xxxviii.-E. macarthuri, sp.nov.

Fig. 1.-Twig with fruits.

Fig. 2.-Twig (sucker) showing stem-clasping leaves.

Fig. 3.-Vertical section through bud.

Fig. 4.-Anther.

Fig. 5.-Buds.

Fig. 6.-Fruits.

Plate xxxix.-E. quadrangulata, sp.nov.

Fig. 1.-Twig with buds and fruits.

Fig. 2.-Twig (sucker) showing quadrangular stems and opposite foliage.

Fig. 3.-Transverse section of young twig, showing quadrangular and winged stem.

Fig. 4.-Vertical section through bud.

Fig. 5.--Anther.

Plate xl.-E. rubida, sp.nov.

Fig. 1. - Twig with buds and flowers.

Fig. 2.-Twig (sucker) showing nearly orbicular foliage.

Fig. 3.--Vertical section through bud.

Fig. 4.-Anther.

Fig. 5.-Fruits in threes, showing cruciform arrangement.

Plate xli., Figs. 1-4-E. goniocalyx (from Bathurst district).

Fig. 1.-Fruits.

Fig. 2.-Buds.

Fig. 3.-Sucker-leaf.

Fig. 4. - Fruits of var. nitens, (var. nov.) 
Figs. 5-9-E. tercticornis.

Fig. 5. - Twig of Allan Cunningham's E. dealbata, collected by himself at Wellington Valley.

Fig. 6.-Leaf of same.

Fig. 7. - Usual size of fruit and pedicel in N.S.W. specimens.

Fig. 8. - Nearly sessile form, from Tenterfield.

Fig. 9.-Small-fruited, short-pedicelled form common in var. latifolia.

Plate xlii., Figs. 1-4-E. saligna, var. parviflora.

Fig. 1.-Mature leaf.

Fig. 2. - Half-grown leaf.

Fig. 3.-Sucker-leaf.

Fig. 4.-Fruits.

Fig. 5-7-E. Gunnii, var. glauca.

Fig. 5.-Mature leaf.

Fig. 6.-Buds.

Fig. 7.-Fruits. 


\section{$2 \mathrm{BHL}$ Biodiversity Heritage Library}

Deane, $\mathrm{H}$ and Maiden, J. H. 1899. "Observations on the eucalypts of New South Wales. Part V." Proceedings of the Linnean Society of New South Wales 24, 448-471. https://doi.org/10.5962/bhl.part.7678.

View This Item Online: https://www.biodiversitylibrary.org/item/21735

DOI: https://doi.org/10.5962/bhl.part.7678

Permalink: https://www.biodiversitylibrary.org/partpdf/7678

\section{Holding Institution}

MBLWHOI Library

\section{Sponsored by}

MBLWHOI Library

\section{Copyright \& Reuse}

Copyright Status: NOT_IN_COPYRIGHT

This document was created from content at the Biodiversity Heritage Library, the world's largest open access digital library for biodiversity literature and archives. Visit BHL at https://www.biodiversitylibrary.org. 